\title{
The Way to Improve Students' Ability to Identify Social Thought in the College Ideological and Political Education
}

\author{
Wei Ling,Yu Huan \\ Yunnan Normal University,Kunming 650500, China
}

Keywords: Colleges, Ideological and political education, Social ideological trend, Analysis ability.

\begin{abstract}
The college ideological and political education is brought by numerous dazzled, complex, changeable and other diversification of social thought. The efficiently and correctly respond to these social trends is not only the primary task of the college ideological and political course, but also cultivates and improves college students' ability to identify social thought, and at the same times it is also the ideological and political education reform need. In order to efficiently and correctly dealing with social thought, we need to improve college students' ability to discriminate, politics course should accurately find the point of the social thought from multi aspects to improve students' theoretical analysis ability. At the same time, we carry out the practical teaching related to the social thought, so we should actively develop network teaching. Teachers should make clear the purpose of teaching in the combination of political education and social thought, so we can positive and effective deal with the social thoughts to bring ideological and political education challenges.
\end{abstract}

\section{Introduction}

With the accelerated pace of economic globalization and China's deepening reform of the overall firm stance to promote all-round, social thoughts are an unprecedented active in different world regions and countries, these numerous dazzled, complex and changeable social ideological trend continue influx, and it gives the thinking of our society and people to bring great influence [1-3]. University and other institutions of higher learning as the key areas of social thought origin and spread, the influence of social thought on the social trend of thought is obvious. Positive and positive energy social thought can develop and enrich the students' knowledge width and the depth of thinking. Conversely, negative social thoughts can play a negative role in the healthy development of students' sanguan [4-6]. In view of this, correct and efficient processing complex dazzling and complex social trend of thought is the primary task of the university ideological and political course $[7,8]$. In theoretical research, research workers in universities often just carry out analysis and discussion from the social thought formation, spreading way and characteristics or from the college students' life view, values, world outlook influence and other object factors, and they ignore the perspective of the subject to analyze and discuss college ideological and political education about dealing with social thought path [9-11]. The ideological and political education in universities is the basis of correctly dealing with diversified social thoughts, in which improving the ability of students is great significance to identify the social ideological trend. This paper will focus on analysis and discussion how to combine course content with social thought effective in the college ideological and political courses, and it can improve the ability of college students to the diversity of social thought in teaching

\section{The Importance of College Ideological and Political Education to Improve the Ability of College Students' Social Trends}

To analyze and study the college ideological and political education can improve the ability of college students to identify the social ideological trend that is an effective way to deal with and resist the bad social thoughts [12-13]. People was built on the subject's self-recognition and approval on the idea problems, if they can actively treat diversified social thought on the impact of college students, we need to improve the students resist unhealthy thoughts ability, but also is to improve the ability of high school students to analyze and identify the trends of social thought. 
At present, China is in a critical period of social transformation, various social trends are unprecedented active. With these diverse social thoughts spread in universities, college ideological and political education workers should respond quickly, actively explore the socialist core value system is effective ways of leading social thoughts, to cope with the challenges of social thought. In the continuous deepening of reform and opening up, social thoughts is spreading in our country, although the college teacher can avoid sensitive topics in the classroom, the students in the class can still receive these complex chaos and complex social thought. College ideological and political teachers should fully respect students, and they should be equal dialogue to improve college students' use of the socialist core value system to identify the trends of social thought, let the students in the analysis and comparison to realize the diversified social thought, to strengthen the ability to identify the bad social thoughts and to the high degree of the socialism.

The cultivation and improvement of college students' identification bad social thoughts is the urgent task of ideological and political education reform in colleges. College ideological and political course cannot always stay on the basis of earlier, it should be changed, the teaching content and form of the course should follow social changes in real time to adjust and reform, making the ideological and political course and the society as well as people's development effectively combine together, or thinking and political work will lose the sense of the times, thereby losing its vitality. At present, numerous dazzled and complex changeable diversified social thought trend increases ceaselessly in China's colleges spread, in which some of the bad or wrong social thought has a serious impediment on college students' correct sanguan formation, such as money worship, pessimistic doctrine, xenophile doctrine and so on. Therefore, college ideological and political education should be changed according to the specific situation of the society, to carry out adjustment and reform in teaching contents, forms and ideas. In teaching content, this paper adds to social ideological trend analysis and comment module, it active studies the criteria and the combination of the diversified social thought in the teaching of ideological and political course. Through the analysis and comment of the complicated and changeable social thought in the teaching, it can directly address college students facing the social reality of processing and the ability, not only to improve the reality and pertinence of college thought political education content, but also to improve the discrimination of college students social thought consciousness and thinking.

Because of the strong theoretical and logical thinking, the ideological and political courses in colleges are especially able to train students to identify the social ideological trend. At present, China's ideological and political courses are usually based on a set of theoretical knowledge, and then the use of the emotional and innovative social trends can meet the students' desire for knowledge. Therefore, the analysis and criticism of the bad social thought is not just a critique of the individual wrong views, but also should complete criticism based on the basic theory of Marx. Ideological and political courses in colleges are extremely careful logic. In the teaching process, if we can use the basic principle to analysis and study, there are numerous and dazzling and complex changeable diversified social thought, especially easy to let the students caused by bad social ideological trend of wrong cognition. People take the form of reasoning speak, students understand bad social ideological trend of the absurd, to do "theory as thoroughly can persuade". In addition, social ideological trend mainly contains the philosophy, politics, economy, culture and other related knowledge, and the ideological and political course content arrangement is highly consistent, which contributes to ideology and politics and the social ideological trend in teaching to carry out in-depth analysis and research. In the course of teaching, the teachers should carry out the comparative analysis, and then carry out the demonstration guidance, to cultivate the ability of college students to identify the social ideological trend.

\section{To Improve and Cultivate the Ability of College Students to Identify the Social Ideological Trend}

In recent years, with the promotion of the reform of ideological and political education curriculum in the ministry of education, learning courses focus gradually by the knowledge of indoctrination to the identification of the subject direction [14]. In the aspect of teachers' teaching, the emphasis of the 
course teaching is to pay more attention to improve students' ability than knowledge. In the course of ideological and political courses in colleges, we should improve and cultivate the ability of students to identify the social ideological trend in the background of this reform. So, in the daily teaching in colleges, we can combine the ideological and political course with the social ideological trend in four aspects [15]:

Looking for the fit point of the ideological and political course and the social thought. In the teaching, we should grasp the focus of the teaching task, and we may be the precise search for the fit point of college ideological and political courses and social ideological trend. This paper carries out effective analysis and research on the social thought.

(1) In the view of the choice of the social thought teaching

In the combination of ideological and political courses and social thought, college teaching may be because of the time and the teaching content and other related conditions, it is necessary to have for the combination of teaching, focusing on explaining the spread widely and easily leading to college students' bad ideas of negative social thought in the university campus, such as historical nihilism, pessimistic doctrine, xenophile and Marxism "outdated" and other thought.

(2) Focusing on the analysis of the basic ideas of social trends

In the analysis and commentary of social thought, this paper focuses on the analysis of its views in philosophy, politics, economy, culture and other aspects, guiding students to understand the positive and beneficial the importance of social ideological trend, to understand the nature and harm of wrong social thought. At the same time, let students consciously learn to understand positive social thought and boycott bad thoughts.

(3) To effectively attack the undesirable social thought

In the case of judging the basic contradiction of capitalism, focus on the interpretation of the new liberalism is the theoretical nature from state monopoly capitalism to international monopoly capitalism services; at the same time, the analysis and study of Marxism Leninism scientific and revolutionary use the new liberalism theory knowledge on Marxism "out of date" to refute. In the ideological and political education, we identify the entry point of the bad social ideological trend, to carry out the real and effective attack.

Theoretical analysis can improve the ability of college students to identify the social ideological trend. In today's society, there are all kinds of social thoughts, they have their own unique principles as a support, and have a strong logic. Therefore, teachers are in teaching, they cannot fail to note reason to point out what kind of thought is correct or not on the students, and they must convince people by reasoning. Ideological and political course is the curriculum theory of the system, and it has the very strong logicality and system. In teaching, if we can use Ma Yuan's basic theory to carry out effective attack for the bad social ideological trend, it can not only reveal the charm of Marxism, but also can greatly enhance the students on the high degree of identity of Marxist sense. For the misconceptions of the bad social ideological trend, we can from the philosophy view and political view to analysis and comment. First, in philosophy, we can use materialist conception history to analyze the essence of socialist democracy; in political, Democratic Party uses the bourgeois democracy to the proletariat's liberation, it denies the functional significance of the class attribute and the ruling class, but we can carry out refute by using the basic principle of Marxism about the national essence and function attribute. In addition, in the teaching, we should pay attention to train students by using the basic theory of Marx and the ability of social thought to analyze and study.

To carry out and strengthen the practice teaching with the social trend. College ideological and political courses not only impart theoretical knowledge, but also cultivate and improve students' ability to analyze and solve problems. College ideological and practical political teaching covers all the teaching aspects beyond the theoretical teaching, so we carry out and strengthen social thoughts related to the practice teaching, it is to cultivate students' innovative spirit and practice ability, enhance comprehensive quality and enhance the basis and premise on the discrimination ability of social thought. To deepen the teaching reform of ideological and political course, we should innovative training model and improve the quality of personnel training, there are important and 
far-reaching significance. Therefore, practice teaching is training students to analyze the key of social thought ability. First, we can optimize the practice teaching system. College ideological and political education should be according to the personnel training objectives, combined with the specific requirements of students' knowledge, ability and quality structure, to carry out the design and optimization of the system for the practice teaching content, organization form and teaching methods and so on. We should reasonable increase the embodiment of comprehensive, design and innovative experimental training projects, combining with the teaching emphasis and social thoughts. Secondly, we can organize the students to discuss the theme of social trends, giving students equal opportunities to communicate and explain their views, and to correctly grasp the social thought in the exchange and collision. Finally, we guide students to carry on the special research of social thought combining with the teaching content, and the students are required to collect and collate relevant information, completing the writing and publication of the relevant papers.

Actively carry out the network teaching. In the internet highly developed today, we actively respond to the opportunities and challenges on college ideological and political courses brought by the internet and the era of big data, we carry out training and research of blended teaching pattern though upgrading network teaching platform, adapting to develop social interaction and hybrid teaching, and emphasizing the importance of network education. Due to limitations of the teaching content and practice, teachers could not analyze and interpret on all the social thought, but they can take advantage of campus network, QQ discussion group or micro channel group to discuss the social thought related to our daily life. Encourage students express their opinions and ideas, the teachers comment, and the teachers actively guide students to identify social thought ability, to realize the teacher and student, students' real-time and non-real time interaction, this method creates a learning knowledge, methods, cooperation spirit and friendship platform for students. Active network teaching can not only expand the teaching content and overcome the shortcomings of the ideological and political theory and real life, but also can improve the enthusiasm of students, which can improve the attractiveness of ideological and political courses.

\section{Ideological and Political Course Teachers' Influence on Students' Ability to Discriminate Social Ideological Trend}

Ideological and political course teachers in colleges have a great influence on the cultivation of students' ability of ideological and social thoughts, and the teaching quality of teachers has a direct impact on ideological and political education, so teachers should pay attention to some problems in teaching:

To clear the purpose of the combination of ideological and political course and social ideological trend. Thought politics curriculum and social thought combined with teaching can develop students' horizons, but more important is to cultivate and improve the ability of students to identify the trends of social thought, and can resist some bad social ideological trend on the students' thinking cause adverse effects. Therefore, teachers should carefully prepare lessons before teaching and clarify the relationship between teaching content and social thought, and then they identify the two entry points. According to the specific situation of the social change, we carry out adjustment and reform in terms of teaching contents, forms and ideas, and point out the significance of the positive social thought. Using reasonable and legal theory enables students to understand the error source and harm of the social thought.

Contact with the truth of our country to analyze the social thought. Nowadays, the theory of ideological and political education in colleges has low relevance with the reality, ideological and political class cannot override the life, but we should contact the reality of our country. The spread of social thought is so popular, because it is closely related to the problems of college students. Therefore, we should focus on college students' hotspot problem on the social thought. For example, we should be combined with the status quo of China's democratic development for the analysis of the universal theory, and we carry out comparison on developed countries democracy and our country democracy; for the analysis and discussion of historical nihilism, we are combined with the history of our party, so that the students can understand the importance of the one party state. Therefore, it is not 
empty to exercise and cultivate the ability of college students to identify the social ideological trend, and we should be closely linked with the truth of our country.

\section{Summary}

As the main channel and the main position of ideological and political education, ideological and political education in colleges is influenced by numerous dazzling and complicated diversified social thoughts. In the face of the continuous influx of social thought around the world, the training and cultivation college students' social ideological trend analysis ability is particularly important. This paper focuses on the analysis and discusses how the ideological and political course and social ideological trend together effectively, we should improve the college students' ability to identify diverse social thought, and require teachers to pay attention to the negative social thought on college students' influence. Closely combined with the teaching content, this paper carries out and strengthens social thought in the teaching practice, and then constructs the teaching mode of trinity from three aspects of classroom, practical and network. For exercises and training ability of students to identify social thought, it makes students to have the ability to resist the bad social ideological trend, which can objectively and comprehensively the social trend of thought in effective analysis.

\section{Acknowledgments}

The work was supported by the Philosophy and Social Sciences Planning Project of Yunnan Province with the project number QN2015010 and the project name Research on the Influence and Countermeasures of Contemporary Chinese Non-Marx's Social Thought on College Students' Thoughts and Behaviors.

\section{References}

[1] Y.X. Sun. The teaching reform of ideological and political course under the impact of social thoughts. Journal of Huaibei Normal University, 2014(2):182-185.

[2] J. Zhang. A review of the social thought and its influence on the college ideological and political education since the reform and opening up. Journal of Wuhan Technical College of Communication, 2014(2): 27-30.

[3] J. Chen. How to cultivate college students' ability to discriminate social trends of thought in the course of ideological and political education. Journal of Huaibei Normal University, 2014(4): 152-155.

[4] S.P. Cheng. A review of the research on the influence of contemporary college students' pluralistic social thoughts. Journal of Heilongjiang Education College, 2015(3): 93-94.

[5] Y.X. Sun, J. Chen. The construction of college ideological and political course under the impact of social thought. Journal of Huaibei Normal University, 2015(4): 37-41.

[6] X.Y. Ding. The challenge of ideological and political theory course under the background of the social thought. Inheritance, 2015(9): 60-61.

[7] F.M. Jiao, Q. Wu. Analysis of the ideological trend of democratic socialism on the negative influence and its countermeasures of college students. The party building and ideological education, 2014(28): 53-55.

[8] B.J. Yue. The diversification research on the socialist core value system to lead the social thought. Henan Agricultural University, 2014: 1-12.

[9] H. Xiao. The effective mechanism of building a socialist core value system to lead the social thought. University of Electronic Science and Technology, 2014(2): 55-58,70. 
[10] X.Z. Zhou. The influence and countermeasures of contemporary social thoughts on college students' ideological and political education. Hebei Normal University, 2014: 1-9.

[11] L.Y. Li. Study on the influence of social ideological trend on the ideological and political education of college students and its countermeasures. Shenyang Normal University, 2014: 2-11.

[12] J.Q. Xu, W. Zhu. Leading diversified social thoughts is an important task to maintain the stability of colleges. Theory, 2014(22): 246-247.

[13] X.H. Lei. The features and countermeasures of contemporary social thoughts on College Students' Ideological Penetration. Xinyang Normal University Journal, 2014(5): 29-32.

[14] H.Y. Peng. The influence and countermeasures of western social thought on the construction of the socialist core value system. Huazhong Normal University, 2014: 1-12.

[15] S.T. Sun. The way and method of ideological and political education leading the social thoughts. Journal of Liaoning University of Technology, 2013(5): 69-71. 